\title{
Ending the Mother Ghost: Beckett's Ill Seen Ill Said and Rockaby
}

\author{
Adam PIETTE \\ University of Sheffield, UK \\ School of English \\ a.piette@sheffield.ac.uk
}

\begin{abstract}
This paper looks at two late texts written in 1981 by Samuel Beckett, the novel Ill Seen Ill Said and the play Rockaby, and reads them as difficult Oedipal elegies for his mother May Beckett who had died thirty years previously. The close reading of the texts brings out the conflicted psychoanalytic contradictions of the representations, especially the son's strange identification with the mother brought on by the fact Beckett was himself approaching his mother's age when she died. The close readings also argue for a 'sentimental' reading of the lyric patterning of both novel and play at key moments, using Simone de Beauvoir's work on old age and her mother's death as reference points. The article ends with a definition of the Oedipal identification as a Memnon complex, where the son and mother fuse together as writing and dying subjects.
\end{abstract}

Keywords: mother love, Oedipal desire, life and death writing

Beckett went through a difficult period when he was psychoanalysed as young man to cure him of his mother fixation. The fixation had psychosomatic symptoms which were quite debilitating: "a bursting, apparently arythmic heart, night sweats, shudders, panic, breathlessness, and, at its most severe, total paralysis" (Knowlson 1996: 176). He saw psychotherapist Wilfred Bion over two years, 1933-35 (aged 27-29), at the Tavistock clinic in London, doing what is called reductive analysis, discovering the dynamic links between symptom and causes in the past:

The search was by free association and dream analysis for what [J.A.] Hadfield termed "nuclear incidents." These need not necessarily be grossly traumatic, but were crises or turning-points in the inner life of the child, as recollected on the couch. The patient relived and realized a repression of one attitude - for example, dependence - by adopting a new attitude - for example, defiance - and a splitting off of his need for love, etc. (Quoting H.V. Dick, Fifty Years of the Tavistock Clinic, Knowlson 1996: 176-7)

Beckett in interview with Knowlson recalled the sessions:

I used to lie on the couch and try to go back in my past. I think it probably did help. I think it helped me perhaps to control the panic. I certainly came up with some 
extraordinary memories of being in the womb. Intrauterine memories. I remember feeling trapped, of being imprisoned and unable to escape, of crying to be let out but no one could hear, no one was listening. (10 Nov 1989 interview, Knowlson 1996: 177)

In notes Beckett took from reading in psychoanalytic literature whilst undergoing analysis, he identified with what a marginal note calls "Peter-Panitis," especially the work of Otto Rank:

Anxiety of child left alone in dark room due to his unconscious being reminded of intrauterine situation, terminated by frightening severance from mother. (SB's typewritten notes, qu. Knowlson 1996: 178)

The relationship with his mother was fraught and over-intimate - a love-hate relationship, working both ways to create paralyzing anxiety in the son (mainly through what he called "psychoneurotic" panic attacks) and depressed eccentricity in the mother - what he called in a letter her "coffee-stall emotions" and "Mother's conscientious cafard" (qu. Knowlson 1996: 185). It was the power of her love for and control over him that was eventually to drive him from Ireland to France: "I am," he wrote after this quarrel in 1937, "what her savage loving has made me, and it is good that one of us should accept that finally" (qu. Knowlson 1996: 273).

This relationship with his mother colours everything Beckett writes, from the early comic exercises in Oedipal writing (the story "Yellow" in More Pricks than Kicks has the Beckett alter ego Belacqua Shuah in hospital with a psychoneurotic cyst to his neck (Beckett 2010: 149-64)) through to the ugly mysogyny of the Trilogy, where the dead beat tramps are stumbling towards the mother figure notionally to kill her. But what concerns us here are the late texts of Beckett, written long after May Beckett's death.

She died in 1950 after a long bout of Parkinson's and after many years of widowhood. In the early summer, Beckett's brother wrote to tell him that the disease she'd been fighting for some time was gaining an upper hand: she'd fallen and broken a femur. Beckett rushed back from France: she was in the Merrion Nursing Home, 21 Herbert St, Dublin, overlooking the Grand Canal. Beckett made the most of these visits. May Beckett suffered from dementia brought on by Parkinson's - "Most of the time her mind wanders and she lives in a world of nightmares and hallucinations," he wrote to friend. As James Knowlson writes:

He was profoundly affected by what he described as the "terrible moral and physical distress" that she clearly experienced whenever she surfaced from her state of profound lethargy. He sat watching over her for an entire week, leaving the Nursing Home only when it was absolutely necessary in order to eat or, when he could no longer bear to watch her suffer, to walk disconsolately alone along the towpath of the Grand Canal. Sitting by her bedside, he longed earnestly, yet compassionately that it would soon be "all over and done with, at last." [In a letter, he wrote:] "My mother's life continues its 
sad decline. It is like the decrescendo of a train I used to listen to at Ussy, interminable, starting up again just when one thinks it is over and silence restored for ever." (1996: 382)

When she died, 25 August 1950, aged 79 (born same year as Proust in 1871), Beckett organized the funeral, burying her beside his dead father at the Protestant cemetery at Redford. As Knowlson remarks:

Beckett had been there so many times with her since 1933, planting heather, watching her wash the headstone with a tiny sponge, changing the flowers in the pot that it was hard to believe that their visits were over. (1996: 383-4)

It was only when Beckett himself began to be an old man that he could manage to write obliquely about his mother's death. First was the play Happy Days written on the tenth anniversary of her death. Then followed two texts which I am concerned with here, the best and most haunting of the mother ghost texts - Ill Seen Ill Said and Rockaby.

Ill Seen Ill Said was written in French and published in 1981 - the composition period was between the $26^{\text {th }}$ of October 1979 and the $27^{\text {th }}$ of September 1979 (Krance 1996: 130-1). Beckett was writing to coincide with the $30^{\text {th }}$ anniversary of his mother's death; the compositional period is also marked by Beckett's own aging process - he was entering his 70s, the same age range which saw his mother die. Rockaby was written within the same timescale - 1981 - so again roughly 30 years after May's death. Both texts are clearly about May - Ill Seen Ill Sad recalls the visits to Beckett's father Bill Beckett's graveside at Redford and the "immaculately black" mourning clothes May Beckett always wore (Beckett 1982: 33). Rockaby recalls the rocking chair his mother retired to towards the end of her life:

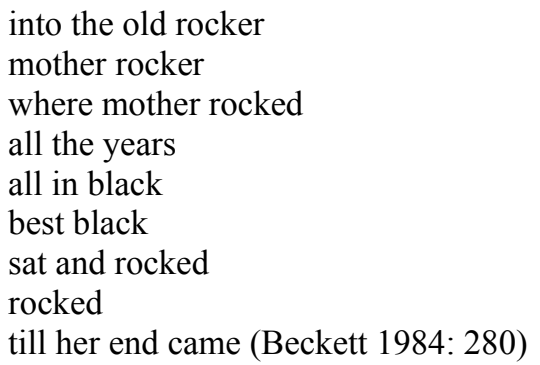

In both texts the gaze of the son on the mother is fraught, the observing mind torn apart by residual anxiety, an anxiety turning on the double desire, both to kill her off, and to feel pity for her state, hate and love. In Ill Seen Ill Said, the mixture is harsh and unbearable. Here Beckett scripts the turn of the narrative gaze upon the solitary dying old woman: 
Already all confusion. Things and imaginings. As of always. Confusion amounting to nothing. Despite precautions. If only she could be pure figment. Unalloyed. This old so dying woman. So dead. In the madhouse of the skull and nowhere else. Where no more precautions to be taken. No precautions possible. Cooped up there with the rest. Hovel and stones. The lot. And the eye. How simple all then. If only all could be pure figment. Neither be nor been nor by any shift to be. Gently gently. On. Careful. (Beckett 1982: 20)

The narrative voice yearns for the end of human presence in his subject, the old so dying woman, and an end also to the presence generated by his own 'I' voice and its 'eye'. An end to the confusion created by the illusion of vocal and subjective presence would be achieved if the text could be interpreted as pure written voice, anonymous, inhuman, dead, pure figment.

The odd nightmarish quality of the text has to do with the fact Beckett's narrative voice is also reading the text he is speaking - he is commenting on it, imagining it as we readers might - Beckett's innovation was to include in the end result of composed text traces not only of the compositional process ("On.") but also traces of implied readers' reactions - the narrator is being presented with a novel, or rather wishing it were all merely a novel he were reading - "If only pure figment." But the tricky thing is that he is not just one impersonal and neutral kind of reader - he is a symptomatic reader, scanning what he is imagining for traces of his own manias, neuroses, Oedipal fixations; trying to act the cold theoretical analyst with her as material - wishing her dead and buried as pure text.

The storyline, such as it is or can be construed from the paragraphs, is that he is an escapee from Dante's $9^{\text {th }}$ circle (the circle reserved for those who betray their kin - as a son who betrayed his mother, or his father as Oedipal rival perhaps). He has come back to earth to check on the very last woman, like Adam or Satan visiting old and solitary Eve. She is dying in her cottage in the fields - this a terminal replay of Wordsworthian pastoral. Her main habit is visiting her husband's grave, like May visiting Bill's. When she moves across the fields she is accompanied by twelve guardian figures - Beckett is playing on the Greek myth of Dawn and Hours, Eos and Horai:

Eos, the Lady of the Morn, wailing her dear child Memnon from the heavens came down. Twelve maidens, the twelve Horai, shining-tressed, attended her, the warders of the high paths of the sun forever circling, warders of the night and dawn. (Smyrnaeus: 2.549)

Eos was the mother of Memnon, her lover was Tithonus - Eos became king of the Ethiopians and fought for the Trojans in the Trojan war but was killed by Achilles. The death of the son causes the mother to mourn, and nature goes into mourning too. The dew is said to be her tears for her departed son, and Memnon became immortal as 
a result of Eon's request to Zeus in the afterlife. The statue of Memnon, represented as sitting, lips about to speak, was said to sing when the dawn sun rose and illuminated the face.

We see Beckett psychoanalytically twisting the Greek material: the Eos-MemnonHorai story is referenced to hint that the mourning process of the mother figure is not for her husband but for her son - an Oedipal hijacking of May's attention to Bill's grave. The mother figure is also represented as occupying the Memnon-statue position at the opening ("From where she lies she sees Venus rise. Followed by the sun") - Memnon is narrating the story as a vision of the mother as dawn.

The symptomatic reader is captured in the text through the powerlessness of the eye to control the old woman's movements. The old woman is a mother figure, a lover, bereaved, desired yet wished dead, and remains outside the narrator's conscious desire to wish her pure figment. The text stages a mother-lover for the gaze, and the eye, at once predatory and desiring, cannot police its own contradictions.

I'd like to concentrate on one paragraph from Ill Seen Ill Said:

Times when she is gone. Long lapses of time. At crocus time it would be making for the distant tomb. To have that on the imagination! On top of the rest. Bearing by the stem or round her arm the cross or wreath. But she can be gone at any time. From one moment of the year to the next suddenly no longer there. No longer anywhere to be seen. Nor by the eye of flesh nor by the other. Then as suddenly there again. Long after. So on. Any other would renounce. Avow, No one. No one any more. Any other than this other. In wait for her to reappear. In order to resume. Resume the - what is the word? What the wrong word? (Beckett 1982: 16-17)

The "other" here seems to refer to the mind's eye. It then seems to mean "anybody else," finally clearing its meanings to refer to "this other." But who this other might be is undecideable. It may be the narrator as symptomatic reader, incapable of sustaining the absence of the fictional object of desire, whose absence he can no longer control. It may also be the figure of one of her twelve guardians, the controllers of time of narrative (crocus time, seasonal time, the times of her appearances and disappearances) equally incapable of letting go of the dearly beloved fictional mother.

It may even refer to the old so dying woman as the defining other to the desiring perceiving subject. The "this other" may refer to her and her incomprehensible staying power, her supposed crazy fidelity to the partner she mourns, madly willing a return of the dead loved one's ghost. She may be a textual matter, a ghostly materialization of textual desires, but she mysteriously lies outside the range of the eye that seeks to resume its unspeakable work on her.

This problem of the "other" - either him or her - may have its source in Simone de Beauvoir, whose book Coming of Age was one of the first to look at old age as a cultural category turning on the difficulty the self encounters when trying to contemplate the other: 
for the outsider it is a dialectic relationship between my being as he defines it objectively and the awareness of myself that I acquire by means of him. Within me it is the Other - that is to say the person I am for the outsider - who is old: and that Other is myself. (De Beauvoir 1978: 420)

De Beauvoir had also lost a mother when old - Françoise de Beauvoir died aged 70 and De Beauvoir wrote a book in 1964 about the 30 days she spent tending her (Une Mort très douce). The moving part of that narrative is her identification with her dying mother:

my despair escaped my control: someone else was weeping inside me [...] my own mouth [...] no longer obeyed me: I'd placed my mother's mouth on my own face and found myself imitating its every little gesture (j'en imitais malgré moi les mimiques). (De Beauvoir1964: 47. My translation)

But everything changes once the observer is the son not the daughter - the mimickry of the mother's face, the watchfulness and imitation become inevitably entangled in the Oedipal script. What is powerfully the case as for de Beauvoir - the radical identification of the accompanying daughter with the departing mother - becomes inflected with the extreme anxieties of Beckett's lifetime struggle with his mother's savage love.

What is clear is that the narrator of Ill Seen Ill Said cannot tell the story straight, is confusing his own imagination with the thing imagined, but is still incapable of understanding the consequences - it is as though Beckett were again on the couch, being asked to inhabit the absent body of his mother again by the analyst, to share her world of nightmares and hallucinations. Writing as imagination is reduced to this incompetent and unreliable exercise in free association and dream analysis. He is asking himself to relive and realize a conflict between attitudes - dependence and defiance - in a bid to split himself off from his need for mother love. But all he manages to do is to betray symptoms of Oedipal anxiety, substituting himself as Memnon into memories of his mother's mourning for his father, forcing her in retrospect to perform her savage love postmortem.

Beckett zooms in on the son's retrospective, yearning gaze and confuses it with the mother's searching desire:

Riveted to some detail of the desert the eye fills with tears. Imagination at wit's end spreads its sad wings. Gone she hears one night the sea as if afar. Plucks up her long skirt to make better haste and discovers her boots and stockings to the calf. Tears. Last example the flagstone before her door that by dint by dint her little weight has grooved. Tears. (Beckett 1982: 17-18) 
In the English, we have "Imagination at wit's end spreads its sad wings." The French from which it derives, or deviates, is "La folle du logis s"en donne à coeur chagrin" (Beckett 1981: 21). The Keatsian tonalities of the English shadow the use by the French of the phrase (said to derive from Malebranche) "folle du logis" to describe the imagination.

The syntax gives ghostly body to the imagination, making it resemble the madwoman in the cabin. The eye is both his imagining her suffering and hers grieving for her lost partner. If the eyes weeping are hers: the old woman is mourning the absence of the dead partner, scrutinizing the landscape for signs of his presence, pitifully weeping at her abandoned old age (the hallucinations, the rediscovery of her forgotten members, the grooves of painful and habitual suffering). If the eyes weeping are his: the eye is weeping at the fact of her absence, the detail of the desert being his own tomb. Whilst weeping, his bereaved imagination retraces memories of her, now figured as the absent mother. As such, she becomes an allegorical figure for the imagination, dying, about to die - because the son is now the same age as his mother was when dying. In gazing at her death he is contemplating his own: the eye is contemplating the death of the son's imagination, destroyed by isolation and madness, exploiting the mother partner as spectacle and as metonym for abandoned male mental processes.

But there is another possibility: one can read the very same words in terms 0 f the subject of the reading resisting representation, resisting being subjected to those practices. For "she can be gone at any time." She can render herself absent from the plangent gaze of mourning and desire. She can absent herself from the narrative desires to exploit her as rhetoric, to summon her up as icon, as object of screen memories, as subject to the disciplinary gaze. She persists out of the range of any representation. Later in the novel, the eye tracks down her face and stares at it, and wishes her dead and gone. But the eyes suddenly open and look the readers and authors back in their faces: "Suddenly the look. Nothing having stirred. Look? Too weak a word. Too wrong. Its absence? No better. Unspeakable globe. Unbearable" (Beckett 1982: 57). The eye cannot "tear itself away from the remains of trace" (59), because transfixed by the ancient Oedipal conflict.

The traces are fixated around the nuclear incidents of his mother's life before her death - specifically her mourning for her partner - the Oedipal conflict continues as the son attempts still to win his mother over from the attachment to the dead husband - but also partly to try and rid himself of her presence all together. The pull between Oedipal possessiveness and murderous desire to kill off her traces is never resolved, because systemic to the imagination.

The fact Beckett was approaching his mother's age when she died is also part of the impact of the text - he is partnering her or hoping to partner her in the manner of his dying: she imagined dying whilst gazing on Venus at dawn, he dying gazing on her as the dawn. Not an orthodox Oedipal complex, then - one might go so far as to call it a Memnon complex. The Memnon complex is this obsession with the dying 
parent as a partner to one's own death - a double act of mourning crossing desire for mother love with violence against her traces mixed in with narrator's own desire for and fear of death: "Absence supreme good and yet. [...] farewell say say farewell. If only to the face. Of her tenacious trace" (Beckett 1982: 59).

But there is another side to the Memnon complex - it is the inescapable tenderness of the vision of the old so dying woman. This is what suddenly lifts the text out of its nest of Oedipal anxieties and psychoneuroses:

From where she lies she sees Venus rise. On. From where she lies she sees Venus rise followed by the sun. Then she rails at the source of all life. On. At evening when the skies are clear she savours its star's revenge. At the other window. Rigid upright on her old chair she watches for the radiant one. Her old deal spindlebacked kitchen chair. It emerges from out the last rays and sinking ever brighter is engulfed in its turn. On. (Beckett 1982: 7-8)

This has the rhythm of poetry, of lyric poetry:

From 'where she 'lies $\mid$ she sees 'Venus 'rise.

On.

From 'where she 'lies

she sees 'Venus 'rise

'followed by the 'sun.

Then she 'rails at the 'source of all 'life.

$\underline{\text { On. }}$.

At 'evening when the 'skies are 'clear

she 'savours its 'star's re 'venge.

'At the 'other 'window.

'Rigid 'upright 'on her old 'chair she 'watches 'for the 'radiant 'one.

Her 'old deal 'spindlebacked 'kitchen 'chair.

It e 'merges from 'out the last 'rays and 'sinking 'ever 'brighter is en 'gulfed 'in its 'turn.

On.

$4-2 / 2 / 2 / 3-3 / 3 / 3-4 / 3 / 4-3 / 3 / 3$

This is a narrative voice composing a poem, an elegy. Intent on heartbreaking detail, in absolute sympathy with and tender attention to the suffering being seen - re-feeling her helplessness, her immobility - finding dignity there, in the beauty of the still statue, the strangeness of her night watching, her vesperal stillness and ending. The prose nearly breaks into song, but this is not "poetic" in the cant sense, but finds an 
elegiac voice through contemplation of the minute particulars of vision/memory of her. Rhymes are discovered, as it were; and rhythmical patterning discovered too on the way - this is Memnon's song at the visionary sight of mother Dawn. The rhymes and rhythms that are discovered time her, follow her slow timing, give ritual shape to the dawn and dusk habits, matching the rhythmical return of stars in sky, Vesper/Venus and sun mimicked by the rhythmical return of sounds and rhythms in voice.

If Ill Seen Ill Said stages the difficult return to sentimental feeling within a murderously broken Oedipal nest of contradictions, how much more tender is the whole play Rockaby. It also features the dying of the mother figure - in her rocking chair seemingly controlled from the wings. The voice is in synch (but not exactly in synch) with the rocking of the chair. The voice-over acts out the role of the "On" voice in Ill Seen Ill Said. The mother figure is dressed in black with sequins picking up the light from the faint spotlight - the contrast with the white of her hair and face and hands very clearly references May Beckett. Her vigil at the window is recalled Beckett is effectively imagining his mother's loneliness when locked away in her dying body. He is seeing her in his mind's eye staged as a being missing all human contacts -especially, clearly, his. But like the old so dying woman in Ill Seen Ill Said, strange energy is discovered in the act of renunciation of life, in the savouring of revenge through her choice of death and a dark end to it all. And just as Ill Seen Ill Said figures secret feeling in terms of the shaping of the voice, what marks out the play is the rhythmical returns and the tight rhyming sounds of the rocking voice returning us as witnesses to her death to the time of lullaby, a rocking to sleep.

The voice remembers her descent into the basement and to her final resting place in the rocker where her own mother had died, pulling down the blind to close off the window so as to have no other to herself any more, just her own dying self. If we turn to the ending of the play, the final lines from "so in the end / close of a long day / went down / in the end went down," the beauty of the image emerges: the rocking chair's arms conjuring human presence, her own mother's arms, the rhyme hinted at between the blinds being pulled down and the closing of her eyes, all turning round signs of dementia signalled by the implied pun in "off her rocker." There is the voice's aggression towards the end (again the shade of Beckett's own analysis coming to head here - the wish to see her dead) but this time it is her desire to rock off the world -lullaby of a rockaby baby falling to death, with the sustained play on "down" as descent into death. There is a quiet echoic beauty to the rhythms and repeats repetition as rhythm of a beating heart ending, body rocking itself slowly to peace at last:

right down

into the old rocker

and rocked

rocked 


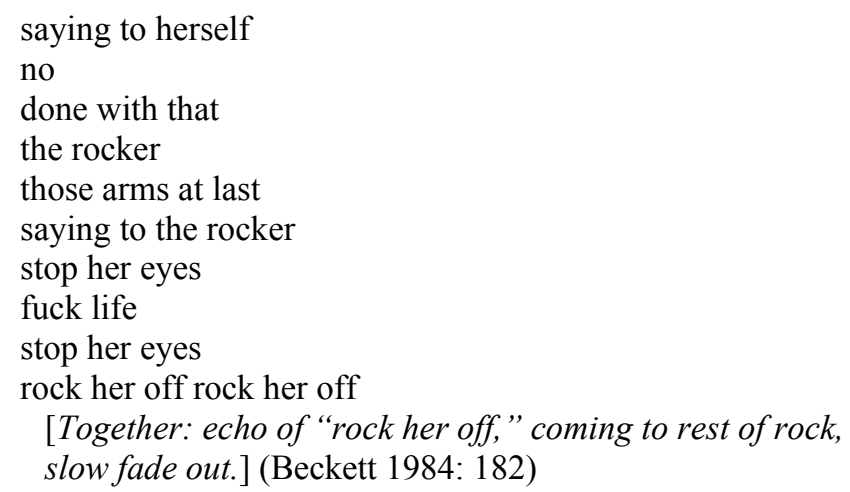

The play ends as it began, with a vision of a dying old woman, sequins glittering in the dark, sinking in the embrace of her rocking chair, with this one difference - her voice narrating her end has achieved this end, as tender termination of breath, body energy, self and voice. It brings to an end, too, Beckett's own complex, conflicted gaze upon the memory traces of his own mother, and terminates his Memnon complex, a final coming to rest of the mother ghost within.

\section{REFERENCES}

Beckett, Samuel (1981). Mal vu mal dit. Paris: Editions de minuit.

Beckett, Samuel (1982). Ill Seen Ill Said. London: John Calder.

Beckett, Samuel (1984). Collected Shorter Plays. London: Faber \& Faber.

Beckett, Samuel (2010). More Pricks than Kicks (1934). London: Faber \& Faber.

De Beauvoir, Simone (1964). Une Mort très douce. Paris: Gallimard.

De Beauvoir, Simone (1978). Coming of Age (1970), Patrick O'Brian, transl., New York: Warner.

Knowlson, James (1996). Damned to Fame: The Life of Samuel Beckett. London: Bloomsbury.

Krance, Charles (1996). Samuel Beckett's Mal vu mal dit/Ill Seen Ill Said: $A$ Bilingual, Evolutionary, and Synoptic Variorum Edition. New York: Garland.

Smyrnaeus, Quintus. Fall of Troy. Theoi Project website http://www.theoi.com/Titan/Horai.html [accessed 11/06/2014]. 